\title{
Measuring the Level of Industrial Green Development and Exploring Its Influencing Factors: Empirical Evidence from China's 30 Provinces
}

\author{
Chaofan Chen ${ }^{1,2, *}$, Jing Han ${ }^{1,+}$ and Peilei Fan ${ }^{2,3,+}$ \\ 1 School of Economics and Resource Management, Beijing Normal University, Beijing 100875, China; \\ nkhanj@bnu.edu.cn \\ 2 School of Planning, Design, and Construction, Michigan State University, East Lansing, MI 488823, USA; \\ fanpeile@msu.edu \\ 3 Center for Global Change and Earth Observations, Michigan State University, East Lansing, MI 488823, USA \\ * Correspondence: ccfforever@163.com or chencf@msu.edu; Tel.: +1-517-505-6374 \\ + These authors contributed equally to this work.
}

Academic Editor: Giuseppe Ioppolo

Received: 5 December 2015; Accepted: 2 February 2016; Published: 15 February 2016

\begin{abstract}
Nowadays, with the green economy becoming mainstream in the world, an industrial revolution as the core of green development has emerged. Based on the empirical evidence from China's 30 provinces, this study establishes an evaluation index system of China's industrial green development and applies the analytic hierarchy process to determine the indices' weights and properties to measure the level of industrial green development in China's 30 provinces. Then, an empirical study is conducted to explore the relevant factors influencing China's industrial green development by using the dynamic panel data model and a panel threshold test. The results show that China's level of industrial green development has the characteristic of typical regional differentiation with a ladder-like distribution from the east and middle to the west, and the eastern region has the highest level on industrial green output, industrial green efficiency and industrial green innovation. Technological progress and innovation can stimulate industrial green development. The impact of environmental regulation and foreign investment on industrial green development presents a nonlinear " $\mathrm{N}$ "-type trend, and the positive effects are mainly observed in eastern China. Capital deepening, heavy chemical industries and an unreasonable energy structure are not effective in industrial green development. There is no direct relation between the enterprise scale and industrial green development.
\end{abstract}

Keywords: industrial green development; assessment and measurement system; analytic hierarchy process; influencing factors; dynamic panel data model; panel threshold test

\section{Introduction}

Industrial production is the main source of modern material wealth and is also a major industry causing environmental and ecological destruction. Environmental problems that were encountered in different processes during the 100 years of industrialization in developed countries have embodied a centralized distribution in China, with structural, compound and condensed forms [1]. Thus, industrial green development is needed to alleviate the conflict between current industrial development and energy, resources and the environment [2,3]. Under this background, the establishment of an evaluation index system for industrial green development is extremely urgent to determine the vulnerable points in industrial transformation, to assess and diagnose the rationality of related policies and to provide a better policy framework for industrial green development. At the same time, industrial 
green development requires the support of a reasonable industrial structure, advanced technology, government policies, etc. In other words, with the deepening of theoretical research and practical processes of industrial green development, the influencing factors are being gradually enriched and expanded.

Since the book "Blueprint of Green Economy" first proposed the concept of the green economy, many scholars have begun to explore the development of the green economy [4]. Up to now, there has been no unified definition of a green economy; the related definitions mostly emphasize "through economic behavior that is environmentally friendly to improve economic and environmental benefits to achieve sustainability" [5-7]. As an important component of the green economy, industrial green development has gradually become the focus of considerable research. Based on the intensive utilization of resources and environmentally friendly, centered on green innovation and the insistence on greening and sustainability in industrial production processes, industrial green development that can be beneficial both economically and environmentally is highly desired.

To date, few studies on an evaluation index system of industrial green development have been presented in China or foreign countries. However, numerous studies have sought to establish an evaluation index system for sustainable development. The Global Reporting Initiative (GRI) [8] published the global sustainable development index, which disclosed the sustainable development of enterprise from economic, environmental and social dimensions. Emerson et al. [9] released the environmental sustainability index that applied an outcome-oriented method to rank countries based on their environmental performance. These studies provided a certain support for quantitatively estimating sustainable development, while they did not set up an evaluation system for green development. With new research on the green economy, research on evaluation indices and methods of measuring green development has become an increasingly important subject in this field. The Organization for Economic Co-operation and Development (OECD) [10] founded a complete index system of green development based on the green growth strategy framework covering all aspects of the economy, environment and human well-being. The index system included four primary indices, 14 secondary indices and 23 tertiary indices. The United Nations Environment Programme (UNEP) [11] published a measurement framework for the green economy that mainly covered aspects of economic transition, resource efficiency, social progress and human well-being. The evaluation system of UNEP was similar to OECD, because they both considered the economic, social and environmental fields. Perry et al. [12] developed the green innovation index system to monitor the green economy performance of the world's 50 largest greenhouse gas-emitting nations, which included five index systems, such as carbon economy, energy efficiency, renewable energy, transportation and clean technology innovation. Although, these studies evaluated green development from the macro-level instead of the industrial level, which could offer valuable references for the establishment of an industrial green development index system.

In China, the most representative achievement of research on a green development index system was the monitoring and measuring index system published by $\mathrm{Li}$ and Pan [13], which used an expert scoring method to measure the green development index of China's 30 provinces. On this basis, domestic scholars studied the index and measurement system of industrial green development [14,15]. Zhang [16] applied a systematic analysis and considered the three aspects of sustainable economic development, sustainable resources supply and sustainable environment improvement as the subsystem level to establish a sustainable development index system of the industrial ecosystem, which included nine primary indices and 46 secondary indices. Su et al. [17] measured China's level of industrial green development from the three aspects of green production, green products and green industry and constructed a performance index of industrial green development using the synthetic index method to evaluate the level of industrial green development in China's provinces. Lu et al. [18] applied the decoupling model to develop an evaluation index system of green industry and measured the level of industrial green development in 21 cities of Guangdong province. The index 
system included the three aspects of environmental pressure of industry, environmental decoupling of industry and greening degree of industry.

Research on how to improve the level of industrial green development requires an analysis of relevant influencing factors. In recent years, scholars have begun to research the influencing factors, which enables the creation of a framework of these studies and also expands the associated theory [19-21]. Brunnermeier and Cohen [22] performed an empirical research on the relationship between environmental regulation and industrial green development using 146 U.S. manufacturing industrial panel data during the years 1983 to 1992. The study showed that investment in pollution control could stimulate the green technology innovation of enterprises to promote industrial green development. Reilly [23] analyzed the interaction between the economic system and the environmental system by using the general equilibrium model. The study showed that environmental policies and investments from the government were important factors for promoting industrial green development. Han and Lan [24] used the Tobit regression method to analyze the factors influencing China's level of industrial greening. The study indicated that technological progress, structure upgrading and economic opening would have a positive effect on the level of industrial greening. Zhang et al. [25] used a panel data model to investigate how environmental regulation, technological innovation and industrial structure would affect industrial green development. They concluded that market-oriented environmental regulation played a main role in areas with high and medium levels of greening, whereas areas with a low level of greening mainly depended on executive-type environmental regulation. Technological innovation and industrial structure were also important factors that affected industrial greening. In addition, scholars noted that strengthening the cooperation of global green industrial management, increasing government financial support, promoting renewable energy and upgrading industrial structure are key factors influencing the industrial green transition [26,27].

The above studies illustrate the widespread and in-depth research on related green development problems from domestic and foreign organizations, experts and scholars. However, research on industrial green development issues is still insufficient. Current research must be improved in at least three aspects. First, there is still no universally authoritative evaluation index system of industrial green development. We can only assess the policy design, implementation process and expected result of industrial green development by establishing an evaluation index system. Second, during the assessment of industrial green development, most scholars focus on the analysis of one specific industry instead of studying regional industrial green development as a whole. Third, although there have been numerous discussions on the influencing factors, the study results are in separate parts, which lack a systematic analysis combining theory and empirical study. To compensate for these shortcomings, in this study, a scientific and objective evaluation system will be built and applied to assess and measure the level of industrial green development of China's mainland provinces. In this process, we draw lessons from the existing research, which mainly include: a systematic evaluation method of industrial green development, related indices that conform to the actual development stage of China's industry, etc. The selection criteria are the principles of relevance, representativeness and operability. On this basis and according to empirical historical panel data, various influencing factors will be explored to provide evidence for China's industrial green development.

\section{Measuring China's Level of Industrial Green Development: A Provincial Comparison and Analysis}

\subsection{Index Selection and Explanation of Evaluation System}

Evaluation system of industrial green development should be based on fundamental principles, such as system comprehensiveness, subject relevance, representativeness and data accessibility. Through investigating the previous literature and considering different dimensions, the criterion layer composed of the industrial green output index, industrial green efficiency index, industrial green innovation index and industrial green policy index is established. On this basis, an evaluation system comprised of 12 secondary indices and 32 tertiary indices is developed, as presented in Table 1. 
Table 1. Evaluation index system of industrial green development.

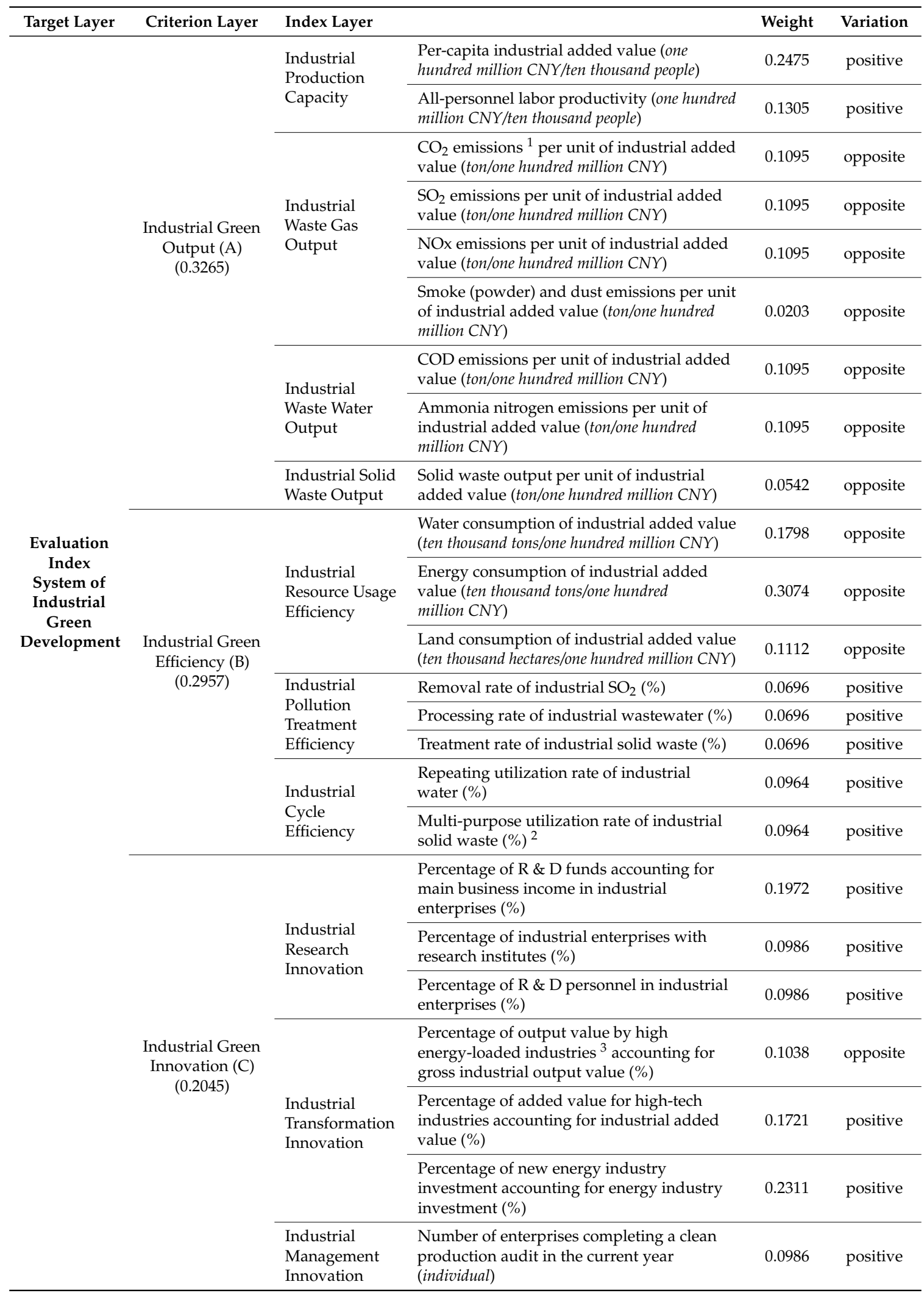


Table 1. Cont.

\begin{tabular}{|c|c|c|c|c|c|}
\hline Target Layer & Criterion Layer & Index Layer & & Weight & Variation \\
\hline & \multirow{8}{*}{$\begin{array}{l}\text { Industrial Green } \\
\text { Policy (D) } \\
\text { (0.1733) }\end{array}$} & \multirow{4}{*}{$\begin{array}{l}\text { Industrial } \\
\text { Environment } \\
\text { Investment }\end{array}$} & $\begin{array}{l}\text { Proportion of industrial pollution treatment } \\
\text { investments in the GDP }(\%)\end{array}$ & 0.2263 & positive \\
\hline & & & $\begin{array}{l}\text { Proportion of industrial wastewater } \\
\text { treatment investment in pollution treatment } \\
\text { investment }(\%)\end{array}$ & 0.1046 & positive \\
\hline & & & $\begin{array}{l}\text { Proportion of industrial waste gas treatment } \\
\text { investment in pollution treatment } \\
\text { investment }(\%)\end{array}$ & 0.1046 & positive \\
\hline & & & $\begin{array}{l}\text { Proportion of industrial solid waste } \\
\text { treatment investment in pollution treatment } \\
\text { investment }(\%)\end{array}$ & 0.0532 & positive \\
\hline & & \multirow{4}{*}{$\begin{array}{l}\text { Industrial } \\
\text { Environment } \\
\text { Control }\end{array}$} & $\begin{array}{l}\text { Total amount of sewage charges }{ }^{4} \\
\text { (one hundred million CNY) }\end{array}$ & 0.2021 & positive \\
\hline & & & $\begin{array}{l}\text { Total effective rules of local } \\
\text { governments }{ }^{5}(\text { item })\end{array}$ & 0.1959 & positive \\
\hline & & & $\begin{array}{l}\text { Projects of "three simultaneousness" } 6 \\
\text { accounting for ongoing projects }(\%)\end{array}$ & 0.0456 & positive \\
\hline & & & $\begin{array}{l}\text { Percentage of environmental supervision and } \\
\text { education institutes }(\%)\end{array}$ & 0.0677 & positive \\
\hline
\end{tabular}

\footnotetext{
${ }^{1} \mathrm{CO}_{2}$ emissions are calculated by the method of 2006 IPCC Guidelines for National Greenhouse Gas Inventories; 2 multi-purpose utilization rate of industrial solid waste refers to the percentage of industrial solid wastes utilized over industrial solid wastes produced (including stocks of the previous years); ${ }^{3}$ China National Economic and Social Development Report indicates 6 high energy-loaded industries, which are: manufacture of raw chemical materials and chemical products; non-metallic mineral products; smelting and pressing of ferrous metals; smelting and pressing of non-ferrous metals; processing of petroleum, coking and processing of nuclear fuel production; and supply of electric power and heat power; ${ }^{4}$ sewage charges refer to collecting the taxes or fees from industrial enterprises that emit pollutants to the environment or the pollutant emissions exceed a certain level; ${ }^{5}$ total effective rules of local governments refer to the current rules that are promulgated by local government and produce an administrative effect; the effective rules are different from the rules that are repealed, invalid, suspended or modified; these data directly come from the China Environmental Yearbook; ${ }^{6}$ the "three simultaneousness" refers to the projects for the prevention and control of pollution must be designed, constructed and put to use or into operation simultaneously with the main part of an industrial construction project.
}

Industrial green output index: The evaluation of industrial green development should give full consideration to the unification of development speed and benefits. In the evaluation of industrial green development, green production is at the core position, which means achieving a minimum negative impact on the environment while expanding the industrial scale and increasing social welfare, employment and industrial products. Based on the above considerations, two parts of the indices are designed under the criterion layer of industrial green output. (1) The indices of per-capita industrial added value and all-personnel labor productivity are used for measuring industrial production capacity, namely accessing the positive output. Per-capita industrial added value reflects the quality and benefit of regional industrial development; higher all-personnel labor productivity indicates a stronger ability to create industrial value. (2) Negative industrial environmental output reflects the environmental performance of industrial development. Industrial pollution is the basic index indicating the impact of industry on the environment, and industrial pollution is mainly reflected in three aspects: industrial waste gas output, industrial wastewater output and industrial solid waste output, i.e., undesirable output in a typical sense [28]. On this basis, seven indices, such as $\mathrm{CO}_{2}$ emissions per unit of industrial added value, are established to specify the industrial pollution discharge.

Industrial green efficiency index: To consider the achievements and shortcomings of industrial green development as a whole, an industrial green efficiency index is designed from three aspects: industrial resource usage efficiency, industrial pollution treatment efficiency and industrial cycle efficiency. (1) Regarding industrial resource usage efficiency, three indices are used: the water consumption of industrial added value is used to evaluate the consumption of the industry in terms of efficiency and water-savings; the energy consumption of the industrial added value is 
the main index to evaluate industrial energy consumption and energy saving status. A lower energy consumption intensity indicates a lower dependency of industrial development on energy [29]; the land consumption of the industrial added value is the index used to reflect intensive production and three-dimensional levels in industry. (2) Industrial pollution treatment efficiency is mainly reflected in the ability of industrial enterprises to treat pollutants, which is measured by three indices: removal rate of industrial $\mathrm{SO}_{2}$, processing rate of industrial wastewater and treatment rate of industrial solid waste. (3) Industrial cycle efficiency includes two indices, namely the repeating utilization rate of industrial water and multi-purpose utilization rate of industrial solid waste. Cycle efficiency is the important index assessing the industrial recycling development level. It reflects whether the industry is transitioning from the linear growth mode of being resource dependent to the ecological mode of relying on resource recycling.

Industrial green innovation index: The realization of industrial green transformation must depend on innovation [30]. In the industrial green innovation index system, three areas are considered: industrial research innovation, industrial transformation innovation and industrial management innovation. (1) Industrial research innovation includes three indices: percentage of R \& D funds accounting for main business income in industrial enterprises, percentage of industrial enterprises with research institutes and percentage of $\mathrm{R} \& \mathrm{D}$ personnel in industrial enterprises, which are important for measuring green innovation capacity from the perspective of technology development. (2) Industrial transformation innovation is used to test the practice of industrial green innovation capacity, which is measured by three indices: percentage of output value by high energy-loaded industries accounting for gross industrial output value, percentage of added value for high-tech industries accounting for industrial added value and percentage of new energy industry investment accounting for energy industry investment. China's industrial structure overly relies on high energy-loaded heavy industry, which is an important reason for the high consumption of energy and resources. Developing the high-tech industry and the new energy industry can not only support the industrial structure adjustment, but also can lead to the green development of the economy and society [31]. (3) Industrial management innovation is also an important manifestation of green innovation. The number of enterprises completing a clean production audit in the current year is used to reflect the level of industrial green management innovation.

Industrial green policy index: Green policy support is an important element to be included in the evaluation index system. The supporting level of regional industrial green policy is reflected by two indices: industrial environment investment and industrial environment control. (1) Industrial environment investment is measured by four indices, such as the proportion of industrial pollution treatment investments in GDP. A larger proportion of industrial pollution treatment investment indicates stronger government support for industrial green development, which is significant for the promotion of local industrial green transformation. (2) The industrial environment control index reflects the government's supervision of industrial green development and includes four secondary indices. Sewage charges are an important means used for measuring market-based environmental supervision, which can influence polluters' decision making through market signals and impel the external costs intrinsically. Under the sewage charges system, each polluter can make a direct response according to the current incentive rates [32]; the total effective rules of local governments and the projects of "three simultaneousness" accounting for ongoing projects are the administrative environment supervisory instruments; the percentage of environmental supervision and education institutes reflects the government's continuous attention to industrial green development. Industrial green development requires the government to combine social forces to extensively participate in and supervise the green transformation of enterprises. 


\subsection{Evaluation Model of Industrial Green Development}

\subsubsection{Comparison Objects and Data Collection}

The comparison objects selected here are Chinese provincial administrative regions. The existing problems in the industrial green transformation can be analyzed by assessing the level of industrial green development of each province. In this line of thought, 30 Chinese mainland provinces are chosen as evaluation units. Because there is an excessive amount of material missing for Tibet, it is not included in the evaluation. To ensure the authority and comparability of the data, data samples are obtained from the China Statistical Yearbook, China Industrial Economy Statistical Yearbook, China Statistical Yearbook on Environment, China Environment Yearbook, China Statistical Yearbook on Science and Technology, China Energy Statistical Yearbook and the Statistical Bulletin and Statistical Yearbook of each province (autonomous regions, municipalities) from 2004 to 2013 [33-39]. The study period is 2003 to 2012, and the data calculations all adopt the average value or average growth rate from 2003 to 2012.

\subsubsection{Setting the Index Weights}

Confirming the index weight coefficient is the core issue of comprehensive assessment. The analytic hierarchy process (AHP) is used to determine the weights of the indices. The specific operations are discussed below.

- $\quad$ First step: the hierarchical model is established. Based on an in-depth analysis of practical problems and in accordance with the well-organized and hierarchical principle, a hierarchical analysis model with the research question is constructed to break down complex problems into individual elements, which are further divided into groups according to their properties to finally form different layers. The analytic hierarchy model is shown in Table 1. The first layer is the target layer, namely the level of industrial green development; the second layer is a criterion layer, namely industrial green output, industrial green efficiency, industrial green innovation and industrial green policy; the third layer is the index layer, which is composed of 32 subdivided indices.

- $\quad$ Second step: the comparison matrix is developed. After determining the hierarchical model among the indices, AHP is used to conduct the comparison of the indices at each layer and to determine their priorities. For instance, if we want to determine the relative importance of each index in the criterion layer of industrial green output, we can construct the comparison matrix $A$ $(n=9)$, which is shown in Table 2. In this step, the expert consultation method is used to develop the comparison matrix. As shown in Table 3, experts repeatedly answer questions in accordance with the $a_{i j}$ evaluation rules, namely comparing to the upper index and the pair-wise comparison among indices at the lower level to determine which index is more important and to what degree. The comparison matrix meets the following conditions: $a_{i j}>0 ; a_{i i}=a_{j j}=1 ; a_{i j}=1 / a_{j i}$. Based on the hierarchical model, the comparison matrices $A, B, C$ and $D$ of the criterion layers are constructed relative to the index layer and matrix $E$ of target layer relative to the criterion layer.

Table 2. The $n \times n$ order comparison matrix.

\begin{tabular}{cccccc}
\hline$A$ & $A_{1}$ & $A_{2}$ & $A_{3}$ & $\ldots$ & $A_{n}$ \\
\hline$A_{1}$ & $a_{11}$ & $a_{12}$ & $a_{13}$ & $\ldots$ & $a_{1 n}$ \\
$A_{2}$ & $a_{21}$ & $a_{22}$ & $a_{23}$ & $\ldots$ & $a_{2 n}$ \\
$A_{3}$ & $a_{31}$ & $a_{32}$ & $a_{33}$ & $\ldots$ & $a_{3 n}$ \\
$\ldots$ & $\ldots$ & $\ldots$ & $\ldots$ & $\ldots$ & $\ldots$ \\
$A_{n}$ & $a_{n 1}$ & $a_{n 2}$ & $a_{n 3}$ & $\ldots$ & $a_{n n}$ \\
\hline
\end{tabular}


Table 3. Scale of the comparison matrix and its description.

\begin{tabular}{cll}
\hline $\begin{array}{c}\text { Relative } \\
\text { Importance } \\
\text { Degree } a_{i j}\end{array}$ & \multicolumn{1}{c}{ Importance Grade } & Explanation \\
\hline 1 & elements $i$ and $j$ are equally important & when two attributes are equally important \\
\hline 3 & element $i$ is slightly more important than element $j$ & slightly important \\
\hline 5 & element $i$ is rather more important than element $j$ & confirmed important \\
\hline 7 & element $i$ is clearly more important than element $j$ & verified important \\
\hline 9 & element $i$ is definitely more important than element $j$ & undoubtedly important \\
\hline $2,4,6,8$ & $\begin{array}{l}\text { the importance of element } i \text { and element } j \text { is between } \\
a_{i j}=2 n-1 \text { and } a_{i j}=2 n+1\end{array}$ & $\begin{array}{l}\text { use the compromising value when two } \\
\text { adjacent values are difficult to judge }\end{array}$ \\
\hline
\end{tabular}

- Third step: calculate the weight. For an $n \times n$ order comparison matrix $A=\left(a_{i j}\right)$, the maximum eigenvalue $\lambda_{\max }$ of the comparison matrix and the corresponding eigenvector $W=\left(w_{1}, w_{2}, \ldots w_{n}\right)^{T}$ of the eigenvalue can be solved, whose components are the weight of $n$ elements or the indices. There are many ways to find the comparison matrix eigenvector $W$, and the root value method is used (see Equations (1) and (2), where $w_{i}$ is the $i$-th component of the eigenvector $W$, i.e., the weight).

$$
\begin{gathered}
\bar{w}_{i}=\sqrt[n]{\prod_{j=1}^{n} a_{i j}, i}=1,2, \ldots, n \\
w_{i}=\frac{\bar{w}_{i}}{\sum_{i=1}^{n} \bar{w}_{i}}
\end{gathered}
$$

- Fourth step: perform the consistency test. In general, changes in the eigenvalues of the comparison matrix are used to verify the degree of consistency. The quantity index used to measure the degree of inconsistency is called the consistency index CI, defined in Equation (3).

$$
C I=\left(\lambda_{\max }-n\right) /(n-1)
$$

where $\lambda_{\max }=\sum_{i=1}^{n}(A W)_{i} / n w_{i}$ is the maximum eigenvalue of the comparison matrix.

The test coefficient $C R$ is obtained by comparing the index with average random consistency index RI, i.e., $C R=C I / R I$. The judging standard is that when $C R<0.1$, then the comparison matrix has satisfactory consistency; otherwise, the element valuing of the comparison matrix must be adjusted. By calculation, comparison matrices $A, B, C, D$ and $E$ all pass the consistency test. After the consistency test, the weight of each index is determined by using MATLAB programming, as shown in Table 1.

\subsubsection{Non-Dimension and the Comprehensive Index}

The dimensionless method "range normalization method" is used to address different indices. A positive index means that the index plays a positive role in industrial green development, as shown in Equation (4); an opposite index plays a negative role, as shown in Equation (5).

$$
\begin{aligned}
x_{i}^{\prime} & =\left[x_{i}-\min \left(x_{i}\right)\right] /\left[\max \left(x_{i}\right)-\min \left(x_{i}\right)\right] \\
x_{i}^{\prime} & =\left[\max \left(x_{i}\right)-x_{i}\right] /\left[\max \left(x_{i}\right)-\min \left(x_{i}\right)\right]
\end{aligned}
$$

Because each criterion layer is comprised of several index layers, functions must be developed for each criterion layer. The linear weighted sum method is used to calculate the indices of the four criterion layers. The criterion layer determines the performance of the target layer, the target layer index calculation and criterion layer index calculation are highly similar; the only difference is the 
weight, and in this study, the weight is an integrated weight reflecting the relative importance of each index layer in the target layer. The weight can be calculated from the weight of the index layer with respect to the criterion layer and the weight of the criterion layer with respect to the target layer, as shown in Table 1. The calculation is as shown in Equation (6). Finally, for comparison purposes, the calculated provincial (autonomous regions, municipalities) rating index is multiplied by 100 to obtain a range of $[0,100]$.

$$
\delta_{E}=w_{A} x_{A}+w_{B} x_{B}+w_{C} x_{C}+w_{D} x_{D}
$$

\subsection{Measurement Results for China's Level of Industrial Green Development}

Table 4 presents the comprehensive index and ranking of industrial green development in China's 30 provincial administrative units, as well as the ranking and indices of industrial green output, industrial green efficiency, industrial green innovation and industrial green policy. The ranking is based on the average index value of each province, and Figures 1 and 2 are based on these values. To perform a more intuitive comparison among the regional levels of industrial green development, the industrial green development index of three regions (east, middle and west) is also measured.

The division of the east, middle and western regions indicates that eight out of the top 10 provinces are located in the eastern region, one is located in the middle and one is located in the west; among the ranking range from 11 to 20, there are two provinces in the east, six in the middle and two in the west; among the ranking range from 21 to 30, there is one province in the east, two in the middle and seven in the west. Overall, the level of industrial green development is highest in the east, followed by the middle and then the west. From the perspective of specific cities, Tianjin, Jiangsu, Shanghai, Zhejiang, Guangdong and Beijing, which are all located in the eastern region, have high levels of green development. The east industrial growth is in a positive transition to the green industry stage. This trend is closely associated with the fact that the eastern region has a higher level of technology, mature management concepts and a sound industrial system. Hebei, Shanxi, Guizhou, Gansu, Qinghai, Xinjiang and Ningxia have low levels of green development. Provinces ranking at the lower end of industrial green development are mainly related to the extensive industrial development model. Industrial growth is obtained at the cost of environmental pollution and resource consumption. This development model is not sustainable in the long term. The eastern region also actively promotes industrial upgrading and transfers traditional outdated industries to the middle and western regions. For example, Beijing and Tianjin have a higher requirement for the level of environmental protection, so more traditional manufacturing industries have been moved to Hebei, Shanxi and other provinces, which negatively impacts their industrial green growth.

Table 4. Index and ranking of China's industrial green development: 30 provinces.

\begin{tabular}{|c|c|c|c|c|c|c|c|c|c|c|}
\hline \multirow{4}{*}{ Province/Region } & \multirow{2}{*}{\multicolumn{2}{|c|}{$\begin{array}{l}\text { Industrial Green } \\
\text { Development } \\
\text { Index }\end{array}$}} & \multicolumn{8}{|c|}{ Criterion Layer } \\
\hline & & & \multirow{2}{*}{\multicolumn{2}{|c|}{$\begin{array}{c}\begin{array}{c}\text { Industrial Green } \\
\text { Output }\end{array} \\
32.65 \%\end{array}$}} & \multirow{2}{*}{\multicolumn{2}{|c|}{$\begin{array}{c}\text { Industrial Green } \\
\text { Efficiency }\end{array}$}} & \multirow{2}{*}{\multicolumn{2}{|c|}{$\begin{array}{c}\begin{array}{c}\text { Industrial Green } \\
\text { Innovation }\end{array} \\
20.45 \%\end{array}$}} & \multirow{2}{*}{\multicolumn{2}{|c|}{$\begin{array}{c}\begin{array}{c}\text { Industrial Green } \\
\text { Policy }\end{array} \\
\mathbf{1 7 . 3 3} \%\end{array}$}} \\
\hline & \multicolumn{2}{|c|}{$100 \%$} & & & & & & & & \\
\hline & Index & Ranking & Index & Ranking & Index & Ranking & Index & Ranking & Index & Ranking \\
\hline Tianjin & 65.96 & 1 & 90.68 & 1 & 72.92 & 9 & 51.85 & 6 & 24.13 & 8 \\
\hline Jiangsu & 64.01 & 2 & 76.12 & 3 & 76.60 & 4 & 63.74 & 1 & 20.03 & 18 \\
\hline Shanghai & 63.35 & 3 & 85.70 & 2 & 72.88 & 10 & 50.41 & 8 & 20.27 & 16 \\
\hline Zhejiang & 60.12 & 4 & 73.44 & 5 & 75.85 & 6 & 53.07 & 5 & 16.50 & 29 \\
\hline Guangdong & 59.73 & 5 & 73.55 & 4 & 74.57 & 7 & 57.66 & 2 & 10.83 & 30 \\
\hline Beijing & 58.41 & 6 & 73.26 & 6 & 78.40 & 3 & 39.83 & 15 & 18.23 & 25 \\
\hline Shandong & 58.14 & 7 & 71.66 & 7 & 78.49 & 2 & 36.58 & 17 & 23.37 & 11 \\
\hline Fujian & 57.91 & 8 & 67.81 & 9 & 76.50 & 5 & 46.12 & 10 & 21.48 & 15 \\
\hline Hubei & 57.27 & 9 & 61.76 & 17 & 80.04 & 1 & 48.84 & 9 & 19.91 & 19 \\
\hline Chongqing & 54.62 & 10 & 62.89 & 13 & 65.76 & 19 & 54.57 & 4 & 20.10 & 17 \\
\hline Shaanxi & 54.33 & 11 & 61.77 & 16 & 71.64 & 13 & 43.46 & 12 & 23.57 & 10 \\
\hline Heilongjiang & 53.38 & 12 & 66.27 & 10 & 65.50 & 20 & 43.94 & 11 & 19.55 & 23 \\
\hline
\end{tabular}


Table 4. Cont.

\begin{tabular}{|c|c|c|c|c|c|c|c|c|c|c|}
\hline \multirow{4}{*}{ Province/Region } & \multirow{2}{*}{\multicolumn{2}{|c|}{$\begin{array}{l}\text { Industrial Green } \\
\text { Development } \\
\text { Index }\end{array}$}} & \multicolumn{8}{|c|}{ Criterion Layer } \\
\hline & & & \multirow{2}{*}{\multicolumn{2}{|c|}{$\begin{array}{c}\text { Industrial Green } \\
\text { Output }\end{array}$}} & \multirow{2}{*}{\multicolumn{2}{|c|}{$\begin{array}{c}\begin{array}{c}\text { Industrial Green } \\
\text { Efficiency }\end{array} \\
29.57 \%\end{array}$}} & \multirow{2}{*}{\multicolumn{2}{|c|}{$\begin{array}{c}\begin{array}{c}\text { Industrial Green } \\
\text { Innovation }\end{array} \\
20.45 \%\end{array}$}} & \multirow{2}{*}{\multicolumn{2}{|c|}{$\begin{array}{c}\begin{array}{c}\text { Industrial Green } \\
\text { Policy }\end{array} \\
17.33 \%\end{array}$}} \\
\hline & \multicolumn{2}{|c|}{$100 \%$} & & & & & & & & \\
\hline & Index & Ranking & Index & Ranking & Index & Ranking & Index & Ranking & Index & Ranking \\
\hline Hunan & 53.35 & 13 & 55.50 & 22 & 69.13 & 16 & 55.46 & 3 & 19.89 & 21 \\
\hline Anhui & 53.12 & 14 & 56.55 & 21 & 71.43 & 14 & 51.22 & 7 & 17.63 & 26 \\
\hline Henan & 53.09 & 15 & 62.11 & 14 & 71.73 & 12 & 40.25 & 14 & 19.46 & 24 \\
\hline Liaoning & 51.37 & 16 & 66.26 & 11 & 73.12 & 8 & 25.39 & 21 & 16.87 & 28 \\
\hline Sichuan & 50.69 & 17 & 57.04 & 20 & 72.22 & 11 & 34.01 & 18 & 21.68 & 14 \\
\hline Neimenggu & 50.41 & 18 & 67.98 & 8 & 63.76 & 23 & 23.98 & 23 & 25.70 & 6 \\
\hline Hainan & 48.66 & 19 & 57.68 & 19 & 59.36 & 25 & 43.40 & 13 & 19.60 & 22 \\
\hline Jiangxi & 47.52 & 20 & 57.90 & 18 & 70.19 & 15 & 24.11 & 22 & 16.90 & 27 \\
\hline Hebei & 47.28 & 21 & 61.90 & 15 & 67.71 & 18 & 15.98 & 28 & 21.82 & 13 \\
\hline Shanxi & 46.14 & 22 & 47.07 & 26 & 63.80 & 22 & 23.69 & 24 & 40.73 & 2 \\
\hline Jilin & 45.53 & 23 & 65.27 & 12 & 61.00 & 24 & 13.34 & 29 & 19.91 & 20 \\
\hline Yunnan & 45.21 & 24 & 52.71 & 24 & 67.73 & 17 & 16.85 & 27 & 26.11 & 5 \\
\hline Guangxi & 42.57 & 25 & 41.18 & 27 & 64.86 & 21 & 29.12 & 19 & 23.00 & 12 \\
\hline Guizhou & 41.47 & 26 & 34.11 & 29 & 59.01 & 27 & 39.70 & 16 & 27.52 & 4 \\
\hline Gansu & 40.96 & 27 & 36.61 & 28 & 59.16 & 26 & 28.23 & 20 & 33.14 & 3 \\
\hline Qinghai & 40.87 & 28 & 51.58 & 25 & 51.76 & 29 & 21.20 & 25 & 25.32 & 7 \\
\hline Xinjiang & 39.62 & 29 & 54.48 & 23 & 55.98 & 28 & 5.49 & 30 & 24.00 & 9 \\
\hline Ningxia & 22.16 & 30 & 10.56 & 30 & 24.60 & 30 & 19.60 & 26 & 42.85 & 1 \\
\hline East, average & 57.72 & 1 & 72.55 & 1 & 73.31 & 1 & 44.00 & 1 & 19.37 & 4 \\
\hline Middle, average & 51.09 & 2 & 60.05 & 2 & 68.51 & 2 & 36.09 & 3 & 22.19 & 3 \\
\hline West, average & 43.25 & 4 & 46.29 & 4 & 59.27 & 4 & 29.22 & 4 & 26.73 & 1 \\
\hline National, average & 50.56 & 3 & 59.42 & 3 & 67.02 & 3 & 36.65 & 2 & 22.22 & 2 \\
\hline
\end{tabular}

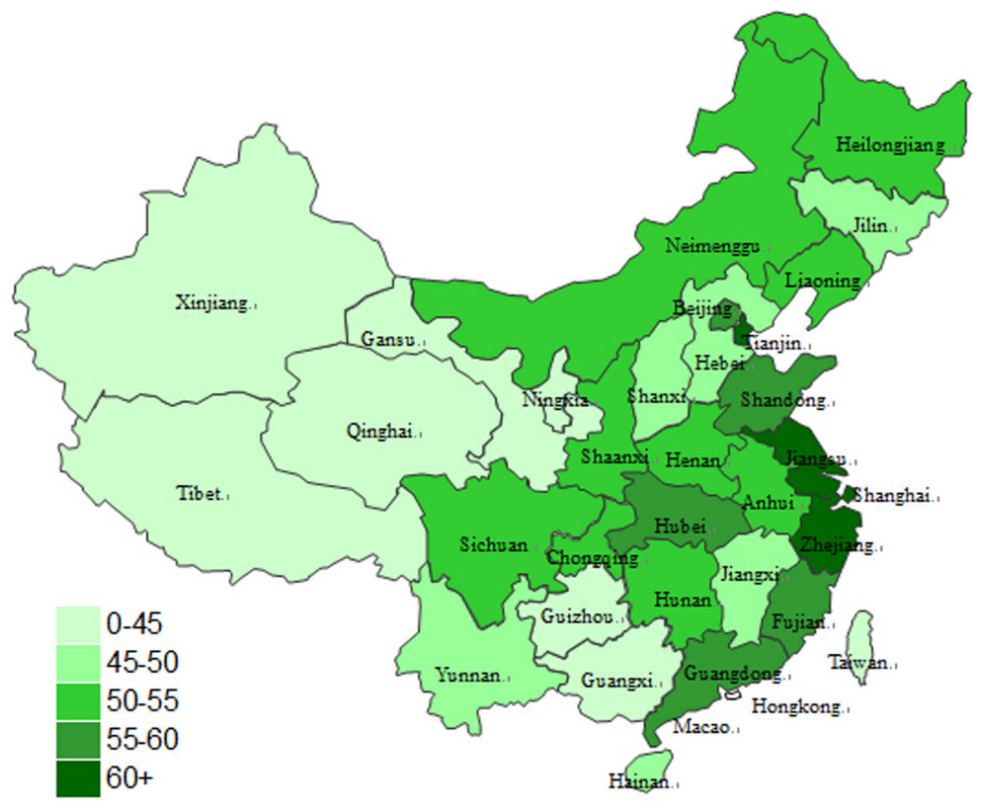

Figure 1. Distribution of industrial green development index in China. Because the sea islands of southern China are not included in the evaluation, they are not drawn in the figure. Tibet, Hong Kong, Macao and Taiwan are assigned the value zero because they are also not included in the evaluation. 


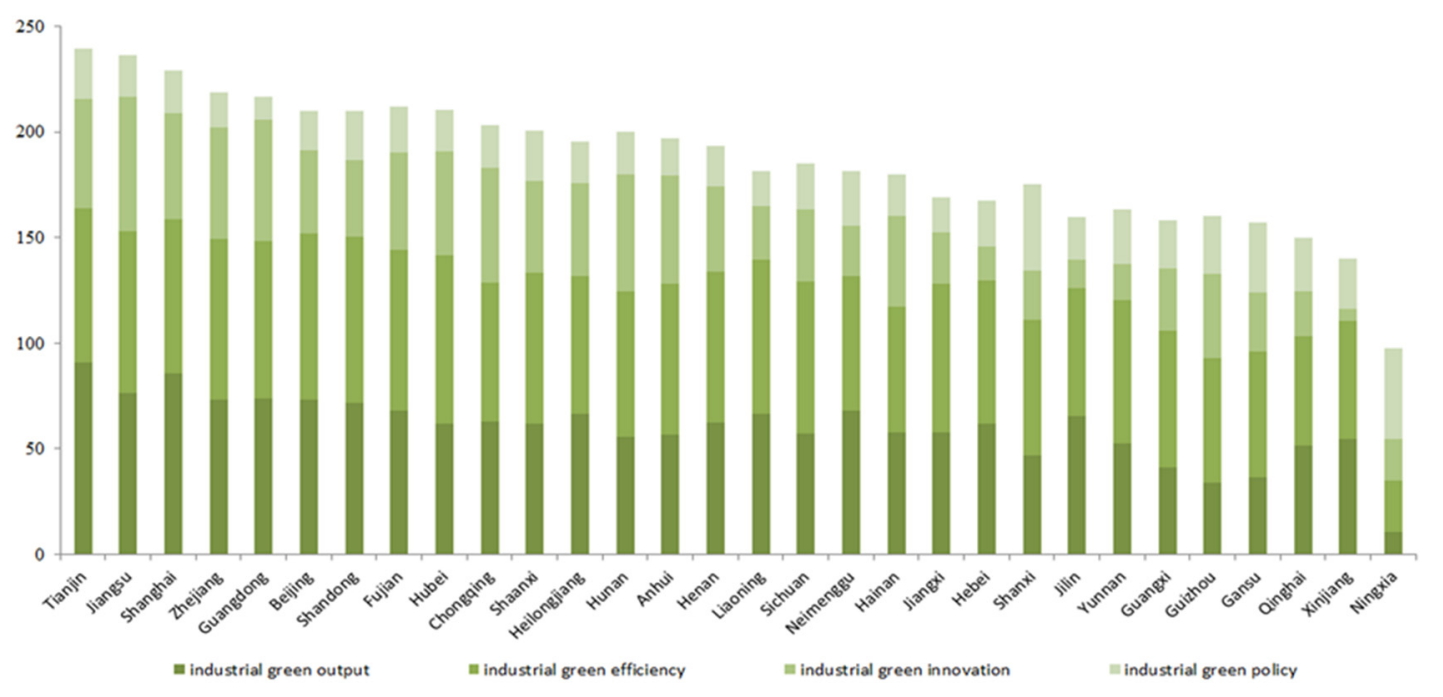

Figure 2. Sub-items of the industrial green development index of China's 30 provinces.

Regarding the four sub-items of the industrial green development index, the eastern region has the highest level on three indices of industrial green output, industrial green efficiency and industrial green innovation, followed by the middle region and then the western region. Regarding industrial green output, Tianjin, Shanghai, Jiangsu, Guangdong, Zhejiang, and Beijing rank highest nationally, which nearly covers the regions with the highest level of economic development in China. The industrial green development and transition will have a good demonstrative effect on other Chinese provinces. Regarding industrial green efficiency, Hubei, Shandong, Beijing, Jiangsu, Fujian and Zhejiang rank highest nationally, which agrees with the fact that the eastern region has a high level of industrial development, but uses low levels of resources. Sustainable industrial development can only be ensured by strengthening intensive and efficient use of resources. Regarding industrial green innovation, Jiangsu, Guangdong, Hunan, Chongqing, Zhejiang and Tianjin rank highest in the country. The most prominent is Jiangsu province, whose driving force of industrial green transformation is science and technology; this province has the highest investments in R \& D funding, the highest number of $\mathrm{R} \& \mathrm{D}$ institutions and the most training for $\mathrm{R} \& \mathrm{D}$ staff. There appears to be an "inverted triangle pattern" in the industrial green policy index, namely that west provinces account for $70 \%$ of the top ten provinces. One reason for this pattern is related to the statistical indicators, for example, although the absolute investment in industrial pollution control in the east is greater than the middle and west, the proportion of investments in industrial pollution control accounting for the GDP is lower in the east than in the middle and west because of the larger economical volume in the east, and thus, the industrial green policy index is generally lower in the east than in the middle and west. Furthermore, although economic development in the middle and western regions lags behind and the local governments are still ineffective in terms of industrial green development, the governments are actively engaged in this topic, dramatically increasing the proportion of investment in pollution control and focusing on strengthening the supervision of industrial enterprises. The central government's policies have led to great responsiveness.

It is important to note that, due to the limitation of data and the difference of provincial material, some indices that indicate the public satisfaction on environmental quality, such as air haze, environmental accidents, etc., have not been included in the evaluation system. Regarding some provinces, although having a higher ranking of industrial green development, such as Beijing and Tianjing, the public satisfaction on the environment is low. Therefore, they should promote industrial green transformation to achieve the public expectation on environmental quality and solve the environmental problems concerning the public in the future. 


\section{Research on the Factors Influencing China's Industrial Green Development}

\subsection{Empirical Model}

China's industrial green development index (provincial panel) is used as the dependent variable in the empirical research. Through the literature review and expert advice, seven independent variables are established: scale structure, endowment structure, industrial structure, environmental regulation, energy structure, technology level and foreign investment. The research period is 2003-2012; thus, a static panel data model is established, as shown Equation (7).

$$
\begin{aligned}
& \ln (\text { lszs })_{i t}=\alpha_{0}+\alpha_{1} \ln (g m j g)_{i t}+\alpha_{2} \ln (\text { bfjg })_{i t}+\alpha_{3} \ln (\text { cyjg })_{i t} \\
& +\alpha_{4}(\text { hjgz })_{i t}+\alpha_{5} \ln (\text { nyjg })_{i t}+\alpha_{6} \ln (j s s p)_{i t}+\alpha_{7}(\text { wstz })_{i t}+\varepsilon_{i t}
\end{aligned}
$$

In Equation (7), $l s z s_{i t}$ refers to the industrial green development index of province $i$ in time $t$. gmjg $_{i t}$, bfjo $_{i t}$, cyjg $_{i t}$, nyjg $_{i t}$, jssp $_{i t}$ and $w s t z_{i t}$ refer to the scale structure, endowment structure, industrial structure, environmental regulation, energy structure, technology level and foreign investment of province $i$ in time $t$, respectively. $\varepsilon_{i t}$ is the random error term. However, the traditional static panel data model may have the endogeneity problems. To eliminate the resulting errors because of endogeneity, the dynamic panel data model based on Generalized method of moments (GMM) estimation is established to perform the empirical analysis.

The difference GMM (DIF-GMM) and system GMM (SYS-GMM) are two important methods in dynamic panel estimation [40,41]. The GMM estimation method can effectively solve the endogenous problem of the independent variables by introducing the instrumental variables into the estimating equation. Studies have shown that the DIF-GMM is easily affected by weak instrumental variables, and under limited sample conditions, the SYS-GMM increases the first-order differential lagging item of the dependent variable as the instrumental variable of the horizontal equation. Thus, the result has a smaller bias than under the DIF-GMM. The dynamic panel data model developed in this study is based on Equation (7), i.e., it is built on the general static panel data model. Thus, the horizontal equation is established first, as shown in Equation (8).

$$
\begin{aligned}
& \ln (l s z s)_{i t}=\kappa_{1} \ln (l s z s)_{i, t-1}+\kappa_{2} \ln (g m j g)_{i t}+\kappa_{3} \ln (\text { bfjg })_{i t}+\kappa_{4} \ln (c y j g)_{i t} \\
& +\kappa_{5} \ln (h j g z)_{i t}+\kappa_{6} \ln (n y j g)_{i t}+\kappa_{7} \ln (j s s p)_{i t}+\kappa_{8} \ln (w s t z)_{i t}+\xi_{i t}+\mu_{i t}
\end{aligned}
$$

The basic concept of the DIF-GMM is to calculate the first-order difference of the horizontal equation, as shown in Equation (9).

$$
\begin{aligned}
& \Delta \ln (\text { lszs })_{i t}=\kappa_{1} \Delta \ln (\text { lszs })_{i, t-1}+\kappa_{2} \Delta \ln (g m j g)_{i t}+\kappa_{3} \Delta \ln (\text { bfjg })_{i t}+\kappa_{4} \Delta \ln (c y j g)_{i t} \\
& \quad+\kappa_{5} \Delta \ln (h j g z)_{i t}+\kappa_{6} \Delta \ln (n y j g)_{i t}+\kappa_{7} \Delta \ln (j s s p)_{i t}+\kappa_{8} \Delta \ln (w s t z)_{i t}+\Delta \mu_{i t}
\end{aligned}
$$

On this basis, the basic concept of the SYS-GMM is to estimate by combining the horizontal regression equation and the differential regression equation. The SYS-GMM is shown in Equation (10). The first equation is the horizontal equation, and the second one is the difference equation.

$$
\left\{\begin{array}{c}
\ln \left(l_{s s s}\right)_{i t}=\kappa_{1} \ln (l s z s)_{i, t-1}+\kappa_{2} \ln (g m j g)_{i t}+\kappa_{3} \ln (b f j g)_{i t}+\kappa_{4} \ln (c y j g)_{i t} \\
+\kappa_{5} \ln (h j g z)_{i t}+\kappa_{6} \ln (n y j g)_{i t}+\kappa_{7} \ln (j s s p)_{i t}+\kappa_{8} \ln (w s t z)_{i t}+\xi_{i t}+\mu_{i t} \\
\Delta \ln (l s z s)_{i t}=\kappa_{1} \Delta \ln (l s z s)_{i, t-1}+\kappa_{2} \Delta \ln (g m j g)_{i t}+\kappa_{3} \Delta \ln (b f j g)_{i t}+\kappa_{4} \Delta \ln (c y j g)_{i t} \\
+\kappa_{5} \Delta \ln (h j g z)_{i t}+\kappa_{6} \Delta \ln (n y j g)_{i t}+\kappa_{7} \Delta \ln (j s s p)_{i t}+\kappa_{8} \Delta \ln (w s t z)_{i t}+\Delta \mu_{i t}
\end{array}\right.
$$

\subsection{Variables Selection}

The dependent variable is the comprehensive index of China's industrial green development, which has been measured. 
The independent variables are selected as follows. (1) Scale structure: This variable is reflected by the proportion of industrial added value of large and medium-sized enterprises in all industrial enterprises. (2) Endowment structure: The capital-labor ratio is used to represent this variable. Capital is obtained according to the perpetual inventory method, and labor is represented by the annual average number of employees. (3) Industrial structure: Under the special condition of industrial green development, the industrial structure is essentially the internal industrial structure, using the heavy chemical industrial output value accounting for the gross industrial output value as a proxy variable. (4) Environmental regulation: Given that the current executive-order environmental regulation in China's industrial development process is stronger than the role of market-based regulation [42], pollution control operating costs accounting for total industrial output value are used to represent the intensity of environmental regulation. (5) Energy structure: For a long time, China's industrial development has had a coal-centered energy consumption structure. The Chinese energy structure must be restructured. The proportion of coal consumption accounting for energy consumption that is converted into standard coal equivalent (SCE) is used to represent the energy structure. (6) Technology level: Technological progress and innovation is the fundamental driving force of the industrial green development. The technical level is most closely related to technological R \& D. Therefore, the internal expense of R \& D funding of above-scale industrial enterprises is selected as the measurement of technology level. (7) Foreign investment: The technological level and the output level of the industry are lifted through technology spillovers of Foreign Direct Investment (FDI) [43]. However, because foreign countries have stringent environmental regulations and policies, they may transfer high energy consumption and high-polluting industries to China [44]. The percentage of industrial added value of enterprises with FDI accounting for the added value of above-scale industrial enterprises is used to measure the level of foreign investment.

The original data of the influencing factors come from the same statistical materials used to measure China's industrial green development, as discussed above.

\subsection{Regression Results}

To maintain stationary data, the logarithm is taken for all original variables. The OLS regression results are obtained based on the established static panel data (Equation (7)), and the SYS-GMM regression results are obtained based on the established dynamic panel data (Equation (10)), as shown in Table 5. For comparison, the regression results of the east, middle and western regions are also provided. The equations in Table 5 are iterated with two-step estimation, and the estimation results are adopted under the condition of robust standard errors.

Considering Table 5, based on the regression results of the static panel data, although the $R^{2}$ value is not high, most regression coefficients are significant, and the coefficient symbols are consistent with our expectations. Thus, the model is considered robust. For the regression results of the dynamic panel data, the corresponding $p$-values of the Sargan statistic are greater than 0.05 , namely the choice of the instrumental variable for each equation is effective. The coefficient joint testing $p$-value verifies that the entire model is highly significant, and the serial correlation test of residual $A R$ (2) proves that there is no correlation in the error terms of original sequence. The lag coefficients of the dependent variables are not significant, indicating that there is not a clear "transfer effect" between the current and previous industrial green development indices. In theory, a good level of previous industrial development will form a demonstration effect and a virtuous cycle, promoting its own industrial green development, but for now, the "transfer effect" of China's industry is still relatively weak, indicating that the capacity of current industrial green accumulation is weak and has not yet formed a continuous "green pushing effect". 
Table 5. Regression results of factors influencing China's industrial green development.

\begin{tabular}{|c|c|c|c|c|c|}
\hline Variable & OLS-National & GMM-National & GMM-East & GMM-Middle & GMM-West \\
\hline $\ln (\operatorname{lszs})_{i, t-1}$ & / & $\begin{array}{l}0.5669 \\
(0.50)\end{array}$ & $\begin{array}{l}0.0816 \\
(0.09)\end{array}$ & $\begin{array}{l}0.5722 \\
(1.20)\end{array}$ & $\begin{array}{l}0.6442 \\
(0.52)\end{array}$ \\
\hline $\ln (g m j g)_{i t}$ & $\begin{array}{l}0.0225 \\
(0.37)\end{array}$ & $\begin{array}{l}0.0326 \\
(0.14)\end{array}$ & $\begin{array}{c}0.2532 \\
(0.50)\end{array}$ & $\begin{array}{c}0.0383 \\
(0.31)\end{array}$ & $\begin{array}{l}0.4623 \\
(0.67)\end{array}$ \\
\hline $\ln (b f j g)_{i t}$ & $\begin{array}{c}-0.1958^{* * *} \\
(-4.43)\end{array}$ & $\begin{array}{c}-0.0457^{* *} \\
(-2.43)\end{array}$ & $\begin{array}{c}0.1209 * * \\
(2.37)\end{array}$ & $\begin{array}{c}-0.0421 * * \\
(-2.04)\end{array}$ & $\begin{array}{c}-0.2876^{*} \\
(-1.86)\end{array}$ \\
\hline $\ln (c y j g)_{i t}$ & $\begin{array}{c}-0.4682^{* *} \\
(-2.13)\end{array}$ & $\begin{array}{c}-0.1530 * * * \\
(-3.31)\end{array}$ & $\begin{array}{c}-0.6303^{* * *} \\
(-3.54)\end{array}$ & $\begin{array}{c}-0.5964 * \\
(1.96)\end{array}$ & $\begin{array}{c}-0.1958 \text { ** } \\
(-2.20)\end{array}$ \\
\hline $\ln (h j g z)_{i t}$ & $\begin{array}{l}0.0036 \\
(0.08)\end{array}$ & $\begin{array}{l}0.0128 \\
(0.09)\end{array}$ & $\begin{array}{l}0.2231^{*} \\
(2.12)\end{array}$ & $\begin{array}{l}0.0600 \\
(0.49)\end{array}$ & $\begin{array}{l}0.7348 \\
(0.98)\end{array}$ \\
\hline $\ln (n y j g)_{i t}$ & $\begin{array}{c}-0.0964^{* *} \\
(-2.02)\end{array}$ & $\begin{array}{c}-0.0016^{* *} \\
(-2.01)\end{array}$ & $\begin{array}{l}-0.1786 \\
(-0.76)\end{array}$ & $\begin{array}{l}-0.1219 \\
(-0.56)\end{array}$ & $\begin{array}{c}-0.5182 * \\
(-1.96)\end{array}$ \\
\hline $\ln (j s s p)_{i t}$ & $\begin{array}{c}0.0574^{* * *} \\
(2.76)\end{array}$ & $\begin{array}{c}0.0216^{* *} \\
(2.27)\end{array}$ & $\begin{array}{c}0.0536^{* * *} \\
(2.67)\end{array}$ & $\begin{array}{c}0.0908^{* *} \\
(2.28)\end{array}$ & $\begin{array}{c}0.6227^{* *} \\
(2.06)\end{array}$ \\
\hline $\ln (w s t z)_{i t}$ & $\begin{array}{c}0.0628 \\
(1.27)\end{array}$ & $\begin{array}{l}0.0466 \\
(0.42)\end{array}$ & $\begin{array}{c}0.0511 * \\
(1.91)\end{array}$ & $\begin{array}{c}0.0732 \\
(0.68)\end{array}$ & $\begin{array}{l}-0.0498 \\
(-0.29)\end{array}$ \\
\hline C & $\begin{array}{l}-0.0035 \\
(-0.12)\end{array}$ & / & / & / & / \\
\hline$R$-squared & 0.589 & / & / & / & / \\
\hline Sargan test & / & 0.385 & 0.413 & 0.372 & 0.398 \\
\hline Wald test & / & 0.000 & 0.000 & 0.000 & 0.000 \\
\hline$A R(2)$ & / & 0.201 & 0.322 & 0.282 & 0.313 \\
\hline
\end{tabular}

$* * * * * *$ represent statistical significance at the $1 \%, 5 \%$ and $10 \%$ levels, respectively. The Sargan statistic is used to test whether there is an over-identified problem. Wald is a coefficient joint test to check the significance of the overall model. $A R(2)$ is the serial correlation test of the residual second-order.

Next, we consider the regression results of each independent variable. (1) Scale structure: The scale structure does not have a significant impact on the industrial green development index. Large-scale industrial enterprises have abundant funding and strong technology to invest in the R \& D of green technology and products, and they often consume large resources and emit high amounts of pollution. Regarding small enterprises, they are smaller but they can adapt to the pace of industrial transformation more rapidly than large-scale enterprises. Furthermore, their resource consumption and pollution emissions are relatively small; thus, the size of enterprises cannot determine their contribution to industrial green development. (2) Endowment structure: The coefficients are significantly negative under the national and the middle and western samples, i.e., capital deepening is disadvantageous in promoting industrial green development, which is consistent with the conclusions obtained by Bing Wang and other scholars $[45,46]$. The reason for this phenomenon could be that the rise in capital-labor ratios tends to be synchronized with heavy industrialization, which in turn leads to further deterioration of the environment. However, the coefficient in the eastern region is positive because the east has a high level of industrial technology and the technical progress of capital-intensive enterprises offsets the negative impact on the environment. (3) Industrial structure: The coefficients of industrial structure are significantly negative, indicating that a greater proportion of heavy chemical industry will hinder industrial green development. This result also verifies that the introduction of policies to prevent the continuous blind expansion of heavy chemical industry is effective, although the way in which these sectors are transferred from the east to the middle and western regions to promote the development of industrialization in inland areas remains debatable. (4) Environmental regulation: Although the coefficients are positive, the performance is significant only in the eastern region. This shows that the impact of environmental regulation on industrial performance has crossed the "Porter point" in the east, which can improve the level of industrial green development. For the 
entire country, particularly the middle and western regions, the positive effect has not been fully exerted. (5) Energy structure: The coefficients are negative and are particular significant under the national samples. The energy structure is one of the most important factors affecting industrial green development. An irrational energy structure not only consumes a large amount of traditional fossil energy sources, but also emits large quantities of harmful substances to environmental systems, which will have serious adverse effects on industrial green development. (6) Technology level: Technological level has a significant positive impact on industrial green development. A higher level of technology is associated with a higher level of industrial green development. Technological innovation improves the enterprise's cleaner production capacities, which can not only improve resources utilization level and productivity, but also can significantly control the emission of pollutants. (7) Foreign investment: The impact of foreign investment on industrial green development is only significant in the east, and its environmental effect has a clear distribution pattern regarding advantages and disadvantages in the east and west. In the east, due to improvements in the quality of foreign investment, foreign enterprises' advanced technology and environmental standards positively affect industrial green development, whereas foreign investment in the west is still focused on high energy consumption, high emissions and other similar projects, which shows that the quality of China's foreign investment attraction still needs to be improved.

\subsection{Further Explorations: Threshold Effect Test}

The above regression results indicate that the influence of scale structure, industrial structure, energy structure and technology level on industrial green development present dynamic linear characteristics. However, there may be a nonlinear relationship between endowment structure, environmental regulation, foreign investment and industrial green development. When taking the linear conclusions as the policy guidance, there will be a deviation in practice. Therefore, a panel threshold model based on Hansen [47] is developed to test whether the impact of the three variables on industrial green development has the threshold characteristic. The threshold effect testing model is shown in Equation (11).

$$
\begin{gathered}
\ln (\text { lszs })_{i t}=\beta_{0}+\beta_{1} \ln (\text { bfjg })_{i t} \times I\left\{\ln (\text { bfjg })_{i t} \leqslant \tau\right\}+\beta_{2} \ln (\text { bfjg })_{i t} \times I\left\{\ln (\text { bfjg })_{i t}>\tau\right\} \\
+\beta_{3} \ln (h j g z)_{i t} \times I\left\{\ln (h j g z)_{i t} \leqslant \tau\right\}+\beta_{4} \ln (h j g z)_{i t} \times I\left\{\ln (h j g z)_{i t}>\tau\right\} \\
+\beta_{5} \ln (w s t z)_{i t} \times I\left\{\ln (w s t z)_{i t} \leqslant \tau\right\}+\beta_{6} \ln (w s t z)_{i t} \times I\left\{\ln (w s t z)_{i t}>\tau\right\}+X_{i t}+\xi_{i}+\mu_{i t}
\end{gathered}
$$

In Equation (11), China's industrial green development index $\ln (\operatorname{lszs})_{i t}$ is the dependent variable; endowment structure $\ln (b f j g)_{i t}$, environmental regulation $\ln (h j g z)_{i t}$ and foreign investment $\ln (w s t z)_{i t}$ are the threshold variables; $\tau$ is the threshold estimated value; and $I(\cdot)$ is the indicator function. The threshold values and significance results of relevant variables are shown in Table 6.

Table 6. Estimated threshold values and significance test.

\begin{tabular}{cccccccc}
\hline $\begin{array}{c}\text { Threshold } \\
\text { Variable }\end{array}$ & $\begin{array}{c}\text { Threshold } \\
\text { Number }\end{array}$ & $\begin{array}{c}\text { F-Statistic } \\
\text { Stat }\end{array}$ & $\mathbf{1 0 \%}$ & $\mathbf{5 \%}$ & $\mathbf{1 \%}$ & $\begin{array}{c}\text { Estimated } \\
\text { Threshold Value }\end{array}$ & $\mathbf{9 5 \%}$ CI \\
\hline $\ln (b f j g)_{(i t)}$ & Single threshold & $5.017^{* *}$ & 2.528 & 3.801 & 6.727 & 3.566 & {$[[2.554,4.138]$} \\
& Double threshold & 1.489 & 2.824 & 4.421 & 7.279 & $/$ & $/$ \\
\hline \multirow{3}{*}{$\ln (h j g z)_{(i t)}$} & Single threshold & $3.841^{*}$ & 2.781 & 3.848 & 6.855 & -5.000 & {$[-6.501,-4.612]$} \\
& Double threshold & $4.426^{* *}$ & 2.889 & 4.265 & 8.402 & -5.757 & {$[-6.501,-4.612]$} \\
& Triple threshold & $4.853^{* *}$ & 2.591 & 3.918 & 6.608 & -5.376 & {$[-6.501,-4.612]$} \\
\hline \multirow{3}{*}{$\ln (w s t z)_{(i t)}$} & Single threshold & $21.596^{* * *}$ & 2.627 & 4.558 & 9.173 & -3.138 & {$[-3.141,-3.138]$} \\
& Double threshold & $6.894^{* *}$ & 2.804 & 3.943 & 7.087 & -2.582 & {$[-3.141,-3.138]$} \\
& Triple threshold & $4.264^{* *}$ & 2.553 & 3.662 & 7.724 & -2.063 & {$[-3.898,-0.814]$} \\
\hline
\end{tabular}

The F-value, relevant critical value and 95\% confidence interval in the table all adopt the "bootstrap method" to perform repeated sampling 1000 times. ${ }^{* * *}, * *, *$ represent significance at the $1 \%, 5 \%, 10 \%$ levels. 
Table 6 shows that taking the $10 \%$ level of significance as the critical line, the endowment structure has single threshold and an estimated threshold value of 3.566; environmental regulation has a significant triple threshold, and its estimated threshold values are $-5.757,-5.376$ and -5.000 ; foreign investment has a significant triple threshold, and its estimated threshold values are $-3.138,-2.582$ and -2.063 . In accordance with the above estimated threshold values, the nonlinear fitting results between endowment structure, environmental regulation and foreign investment and China's industrial green development can be obtained, as shown in Table 7.

Table 7. Testing results of the panel threshold model.

\begin{tabular}{|c|c|c|c|c|}
\hline Sample Interval & Test Coefficient & t-Value & $\begin{array}{l}\text { Fitting } \\
\text { Shape }\end{array}$ & $\begin{array}{c}\text { Optimal Interval } \\
\text { Provinces }\end{array}$ \\
\hline \multicolumn{3}{|c|}{ Endowment structure } & \multirow{3}{*}{ “l”-type } & \multirow{3}{*}{$\begin{array}{l}7 \text { in East; } 3 \text { in } \\
\text { Middle; } 3 \text { in West }\end{array}$} \\
\hline $\ln (b f j g)_{i t} \leqslant 3.566$ & $-0.045^{* *}$ & -2.229 & & \\
\hline $\ln (b f j g)_{i t}>3.566$ & -0.030 & -1.041 & & \\
\hline \multicolumn{3}{|c|}{ Environmental regulation } & \multirow{5}{*}{ “N"-type } & \multirow{5}{*}{$\begin{array}{l}7 \text { in East; } 4 \text { in } \\
\text { Middle; } 3 \text { in West }\end{array}$} \\
\hline $\ln (h j g z)_{i t} \leqslant-5.757$ & -0.023 & -0.486 & & \\
\hline$-5.757<\ln (h j g z)_{i t} \leqslant-5.376$ & $0.076^{* * *}$ & 5.765 & & \\
\hline$-5.376<\ln (h j g z)_{i t} \leqslant-5.000$ & 0.069 & 1.303 & & \\
\hline $\ln (h j g z)_{i t}>--5.000$ & $0.428 * *$ & 1.918 & & \\
\hline \multicolumn{3}{|c|}{ Foreign investment } & \multirow{5}{*}{ “N"-type } & \multirow{5}{*}{$\begin{array}{l}10 \text { in East; } 2 \text { in } \\
\text { Middle; } 2 \text { in West }\end{array}$} \\
\hline $\ln (w s t z)_{i t} \leqslant-3.138$ & 0.019 & 0.695 & & \\
\hline$-3.138<\ln (w s t z)_{i t} \leqslant-2.528$ & $0.044^{* * *}$ & 3.460 & & \\
\hline$-2.528<\ln (w s t z)_{i t} \leqslant-2.063$ & -0.003 & -0.054 & & \\
\hline $\ln (w s t z)_{i t}>-2.063$ & $0.574 * * *$ & 2.519 & & \\
\hline Whether to add other variables & Yes & Yes & & \\
\hline Whether to control an individual effect & Yes & Yes & & \\
\hline
\end{tabular}

Table 6 provides empirical evidence to further analyze the nonlinear impacts of the endowment structure, environmental regulation and foreign investment on China's industrial green development. In terms of endowment structure, the negative influence of capital deepening on the industrial green development will weaken. After crossing the threshold value of 3.566, the coefficient of the endowment structure will rise to -0.030 . In other words, China's industrial structure is in the transition from a labor-intensive phase to a capital-intensive phase, where capital-intensive represents heavy industrialization that will exacerbate the environmental pollution of industry. In contrast, under the "learning by doing" effect, increasing the capital labor ratio will improve technology and the management level, promote technological progress and gradually offset environmental degradation brought about by capital deepening. In terms of environmental regulation, the variations of coefficients in different threshold intervals have the " $\mathrm{N}$ "-type characteristic, which fully demonstrates the Porter hypothesis in China's industrial transformation. In the beginning stage, the influence of environmental regulation on industrial green development is not stable and even restrains the motivation of enterprise transformation, whereas after the threshold value of -5.000 is crossed, environmental regulation will smoothly step over the "Porter point" and achieve a win-win situation for industrial and environmental performance. Regarding foreign investment, its impact on industrial green development also presents the "N"-type characteristic, which confirms the "pollution-haven" hypothesis and "pollution-halo" hypothesis successively. In the initial stage, foreign investment quickly pulls the industrial economic performance and makes the positive effect greater than the environmental negative effect; however, because China attracts a large number of foreign capital at relatively low environmental standards, this led to the deterioration of the ecological environment. Since then, along with improving the 
FDI quality, China can improve the industrial environment level through higher environmental standards and technical spillover. Certain provinces achieve the optimal threshold interval regardless of the endowment structure, environmental regulation and foreign investment; the eastern region is significantly better than the middle and western regions, which demonstrates that the eastern region is in a leading position in terms of technological progress, environmental regulation and FDI quality, which is consistent with the conclusions of the dynamic panel data model. Therefore, the panel threshold testing further demonstrates the rationality and robustness of the GMM estimation results.

\section{Main Conclusions and Policy Implications}

China's level of industrial green development has the characteristic of typical regional differentiation, with a ladder-like distribution from the east and middle to the west. The eastern region has a high level of industrial green development, because after 30 years of rapid development since China's reform and opening up, the industrialization level of the eastern region is significantly higher than those in the middle and western regions. The eastern region optimizes the industrial structure, adjusts the industrial layout and develops high-tech industries to ease the resources and the environmental constraints to improve the level of industrial green development. However, the public is not satisfied with the environmental quality in some east provinces. The environmental problems, such as air haze, have been attributed, in part, to rapid growth of the industrial economy. For the majority of the middle and west provinces, although the resources for industrial production are abundant, industrial development not only consumes a large amount of resources, but also produces a large amount of pollutant emissions. Furthermore, these provinces undertake the traditional and outdated industrial projects that are transferred from the east; thus, the task of industrial green transformation is rather arduous for the middle and western regions. The study of factors affecting industrial green development indicate that technical progress and innovation can remarkably stimulate industrial green development; the impact of environmental regulation and foreign investment on industrial green development presents a nonlinear " $\mathrm{N}$ "-type trend, and their positive effects are mainly reflected and contributed by the eastern region; capital deepening, heavy chemical industry and an unreasonable energy structure negatively affect the green transformation of industry; and there is no direct relation between the enterprise scale and industrial green development. Policy implications derived from the above findings are provided below.

First, the central government should reform the performance evaluation system of political achievement, which takes GDP as the core, and build a performance evaluation system for green economic development. During the reform process, resources, the environment and some other relevant factors must be included in the evaluation. Related limited indices of industrial energy savings and emission reduction should comprise a large proportion of the government rewards and punishment evaluation system. Meanwhile, we can introduce the public satisfaction into the qualification assessment of local government to make the public environmental expectation affect the career of officials.

Second, regional environmental regulation systems must be improved to achieve national industrial energy savings and emission reductions. Local governments should implement differentiated, reasonable and dynamic environmental regulation standards based on the practical conditions of local industrial development. For eastern regions, the command-and-control regulation tools should be changed to market-orientated regulation tools, such as tradable emission allowances, etc., to guide enterprises to actively undertake the responsibilities of energy savings and emission reduction. For the middle and western regions, the power of environmental regulation must be enhanced to stimulate enterprises' innovation in pollution control technologies and production technologies, thereby achieving the win-win of pollution control and emission reductions, as well as the economic benefits.

Third, industrial restructuring must be accelerated, and a green industry system must be established. The traditional industries must be reformed, and outdated capacities must be eliminated. 
Advanced technology standards must be used to enhance the greening level of traditional industries. The goal of cleaner production from end-of-pipe-treatment should be achieved. Green investment should be intensified, and the strategic emerging industry and the new energy industry should be expanded. The strategic emerging industry should be expanded to improve the overall influence of industry in the global value chain, and clean energy and renewable energy resources should be used to optimize the energy structure and increase resource use efficiency.

Fourth, government should invest more in the technological development and research on green industry and focus on upgrading the quality of FDI. Local governments' independent research and development ability of green industries should be strengthened, and the technology standard and management regulation of green manufacturing should be improved. Mutual capital from the government and individuals should be guided to enter the green industrial $\mathrm{R} \& \mathrm{D}$ field. Meanwhile, advanced technology achievements, management experiences and environmental standards should be learned from foreign enterprises in local regions and implemented. For the middle and western regions, when undertaking industrial transfer projects from other regions or overseas, provinces cannot solely focus on the quantity, but should instead carefully select some enterprises with low energy consumption and environmental friendliness that have advanced technology and rich management experiences to achieve the overall green layout of industrial development.

Acknowledgments: This work was supported by Financial support from China Scholarship Council (CSC-201506040125); the New Century Talent Supporting Project by China Education Ministry (NCET-13-0052); and the National Natural Science Foundation of China (71203013). Moreover, Peilei Fan would like to acknowledge the funding support of NASA (Grant \#: NNX15AD51G).

Author Contributions: All of the authors contributed equally to the research design and to this article. Chaofan Chen is the main writer of this paper and contributed to the data collection, empirical modeling and analysis. Jing Han contributed to the evaluation system and conducted the discussion with the experts. Peilei Fan assisted in developing the overall research framework, evaluated the research findings, and edited the manuscript; she also made a contribution to the language revisions.

Conflicts of Interest: The authors declare no conflict of interest.

\section{References}

1. Research Group of the Institute of Industrial Economy of Chinese Academy of Social Science. Research on China's industrial green transformation. China Ind. Econ. 2011, 4, 5-14.

2. $\mathrm{Hu}, \mathrm{A}$. Introduction: Entering the Green Industrial Revolution. In China: Innovative Green Development; Springer: Berlin, Germany; Heidelberg, Germany, 2014.

3. Schmitz, H.; Lema, R. The global green economy: Competition or cooperation between Europe and China? Triple Chall. Eur. Econ. Dev. Clim. Change Gov. 2015, 5, 118-141.

4. Pearce, D.W.; Markandya, A.; Barbier, E. Blueprint for a Green Economy; Earthscan: London, UK, 1989.

5. Hallegatte, S.; Heal, G.; Fay, M.; Treguer, D. From Growth to Green Growth-A Framework; NBER Working Paper; National Bureau of Economic Research: Cambridge, MA, USA, 2012.

6. Li, X.; Pan, J. China Green Development Index Report; Springer Science \& Business Media: Berlin, Germany, 2012.

7. Kerka, G.V.; Manuel, A.R. A comprehensive index for a sustainable society: The SSI-the sustainable society index. Ecol. Econ. 2008, 66, 228-242. [CrossRef]

8. GRI-Global Reporting Initiative. Sustainability Reporting Guidelines Version 3.0; GRI: Amsterdam, The Netherlands, 2006.

9. Emerson, J.W.; Hsu, A.; Levy, M.A.; de Sherbinin, A.; Mara, V.; Esty, D.C.; Jaiteh, M. EPI 2012: Environmental Performance Index and Pilot Trend Environmental Performance Index; Yale Center for Environmental Law and Policy: New Haven, CT, USA, 2012.

10. Organization for Economic Co-operation and Development (OECD). Towards Green Growth; OECD Publishing: Paris, France, 2011.

11. United Nations Environment Programme (UNEP). Measuring Progress towards a Green Economy, Draft Workingpaper; UNEP: Nairobi, Kenya, 2012.

12. Perry, N.; Sarah Henry, S.; Perry, M.; MacArthur, L. California Green Innovation Index-International Edition; Next 10: Palo Alto, CA, USA, 2015. 
13. Li, X.; Pan, J. China Green Development Index Report; Beijing Normal University Press: Beijing, China, 2010.

14. Wang, Y.; Chen, W. Fuzzy assessment on the industrial greening level in riverside cities of Jiangsu Province. Resour. Environ. Yangtze Basin 2008, 17, 170-174.

15. Chen, S.; Golley, J. Green productivity growth in China's industrial economy. Energy Econ. 2014, 44, 89-98. [CrossRef]

16. Zhang, C.; Xue, H.; Liu, H. Sustainable development evaluation index system of industrial ecosystem. In Proceedings of the 2010 International Conference on Management Science and Engineering (MSE 2010), Wuhan, China, 17 October 2010.

17. Su, L.; Zheng, H.X.; Wang, Y. Assessment of industrial green development in China's different provinces. China Popul. Resour. Environ. 2013, 23, 116-122.

18. Lu, Q.; Wu, Q.; Zhou, Y.; Zhou, H. Evaluation index system of industrial green development and apply it to evaluate Guangdong province. J. Ecol. Environ. 2013, 22, 528-534.

19. Smulders, S.; Toman, M.; Withagen, C. Growth theory and green growth. Oxf. Rev. Econ. Policy 2014, 30, 423-446. [CrossRef]

20. Kumar, S. Environmentally sensitive productivity growth: A global analysis using malmquist-luenberger index. Ecol. Econ. 2006, 56, 280-293. [CrossRef]

21. Loko, B.; Diouf, M.A. Revisiting the Determinants of Productivity Growth: What's New; IMF Working Papers; International Monetary Fund: Washington, DC, USA, 2009.

22. Brunnermeier, S.B.; Cohen, M.A. Determinants of environmental innovation in US manufacturing industries. J. Environ. Econ. Manag. 2003, 45, 278-293. [CrossRef]

23. Reilly, J. Green growth and the efficient use of natural resources. Energy Econ. 2012, 34, S85-S93. [CrossRef]

24. Han, J.; Lan, Q. Research on the measurement of Chinese industrial greening level and its influencing factors. China Popul. Resour. Environ. 2012, 22, 101-107.

25. Zhang, J.; Cai, N.; Yang, C. Environmental regulation's effect on Chinese industrial green development index. China Popul. Resour. Environ. 2015, 25, 24-31.

26. Cainelli, G.; Mazzanti, M.; Zoboli, R. Environmental innovations, complementarity and local/global cooperation: Evidence from North-East Italian industry. Int. J. Technol. Policy Manag. 2011, 11, 328-368. [CrossRef]

27. Lewis, J.I. Green Innovation in China: China's Wind Power Industry and the Global Transition to a Low-Carbon Economy; Columbia University Press: New York, NY, USA, 2013.

28. Watanabe, M.; Tanaka, K. Analysis of Chinese industry: A directional distance function approach. Energy Policy 2007, 35, 6323-6331. [CrossRef]

29. Jefferson, G.H.; Rawski, T.G.; Zhang, Y. Productivity growth and convergence across China's industrial economy. J. Chin. Econ. Bus. Stud. 2008, 6, 121-140. [CrossRef]

30. Machiba, T. Eco-innovation for enabling resource efficiency and green growth: Development of an analytical framework and preliminary analysis of industry and policy practices. Int. Econ. Econ. Policy 2010, 7, 357-370. [CrossRef]

31. Lee, C.F.; Lin, S.J.; Lewis, C. Effects of carbon taxes on different industries by fuzzy goal programming: A case study of the petrochemical-related industries, Taiwan. Energy Policy 2007, 35, 4051-4058. [CrossRef]

32. Hockenstein, J.B.; Stavins, R.N.; Whitehead, B.W. Crafting the next generation of market-based environmental tools. Environ. Sci. Policy Sustain. Dev. 1997, 39, 12-33. [CrossRef]

33. Jingping, Z.; Xiaochao, L.; Laiyun, S. China Statistical Yearbook; China Statistics Press: Beijing, China, $2004-2013$.

34. Caifang, R.; Fujiang, L.; Kuankuan, Y. China Industrial Economy Statistical Yearbook; China Statistics Press: Beijing, China, 2004-2013.

35. Jingkui, M.; Jian, Z.; Nailin, F.; Qing, S.; Hualin, Z.; Bingjiang, L.; Jianwu, W. China Statistical Yearbook on Environment; China Statistics Press: Beijing, China, 2004-2013.

36. Yuefeng, Y.; Mingsen, Y. China Environment Yearbook; China environment yearbook press: Beijing, China, 2004-2013.

37. Zhimin, C.; Nan, J.; Xiaojing, G. China Statistical Yearbook on Science and Technology; China Statistics Press: Beijing, China, 2004-2013.

38. Xiangdong, Z.; Yifan, X.; Xianchun, X.; Qin, G.; Jianwu, W. China Energy Statistical Yearbook; China Statistics Press: Beijing, China, 2004-2013. 
39. Bureau of statistics (NBS) of each province (autonomous regions, municipalities); NBS Survey Office in each province (autonomous regions, municipalities). Statistical Yearbook; China Statistics Press: Beijing, China, 2004-2013.

40. Arellano, M.; Bond, S. Some tests of specification for panel data: Monte Carlo evidence and an application to employment equations. Rev. Econ. Stud. 1991, 58, 277-297. [CrossRef]

41. Arellano, M.; Bover, O. Another look at the instrumental variable estimation of error-components models. J. Econom. 1995, 68, 29-51. [CrossRef]

42. Francesch-Huidobro, M.; Lo, C.W.H.; Tang, S. The local environmental regulatory regime in China: Changes in pro-environment orientation, institutional capacity, and external political support in Guangzhou. Environ. Plan. A. 2012, 44, 2493-2511. [CrossRef]

43. Perkins, R.; Neumayer, E. Fostering environment efficiency through transnational linkages? Trajectories of $\mathrm{CO}_{2}$ and $\mathrm{SO}_{2}, 1980-2000$. Environ. Plan. A 2008, 40, 2970-2989. [CrossRef]

44. Deng, Y.; Xu, H. International direct investment and transboundary pollution: An empirical analysis of complex networks. Sustainability 2015, 7, 3933-3957. [CrossRef]

45. Wang, B.; Wu, Y.; Yan, P. China's regional environmental efficiency and environmental total factor productivity growth. Econ. Res. J. 2010, 5, 95-109.

46. Ahmed, E.M. Green TFP intensity impact on sustainable East Asian productivity growth. Econ. Anal. Policy 2012, 42, 67-78. [CrossRef]

47. Hansen, B.E. Threshold effects in non-dynamic panels: Estimation, testing, and inference. J. Econom. 1999, 93, 345-368. [CrossRef]

(C) 2016 by the authors; licensee MDPI, Basel, Switzerland. This article is an open access article distributed under the terms and conditions of the Creative Commons by Attribution (CC-BY) license (http://creativecommons.org/licenses/by/4.0/). 